\title{
Pengaruh Kualitas Sumberdaya Manusia Dan Implementasi Kebijakan Dinas PUPR Terhadap Pembentukan Pola Ruang Di Kecamatan Bissappu Kabupaten Bantaeng
}

\author{
The Influence of the Quality of Human Resources and the Implementation of \\ the Public Works Department's Policy on the Formation of Spatial Patterns \\ in Bissappu District, Bantaeng Regency
}

\author{
Titin Supriyatin ${ }^{1}$, Rudi Latief ${ }^{2}$, Syafri ${ }^{3}$ \\ ${ }^{1}$ Dinas Pekerjaan Umum daa Penataan Ruang Kabupaten Bantaeng \\ 2Program Studi Perencanaan Wilayah dan Kota, Program Pascasarjana, Universitas Bosowa \\ E-mail: titin10juni@gmail.com
}

Diterima: 01 September 2021/Disetujui 12 Desember 2021

\begin{abstract}
Abstrak. Penelitian ini bertujuan mengidentifikasi dan menganalisis bagaimana pengaruh kualitas sumberdaya manusia dan implementasi kebijakan Dinas PUPR Kabupaten Bantaeng secara bersama-sama terhadap pembentukan pola ruang di Kecamatan Bissappu Kabupatren Bantaeng. Metode analisis yang digunakan dalam penelitian ini yaitu pengujian data-data yang diperoleh berdasarkan data times series atau waktu ke waktu berdasarkan data yang dikumpulkan selama interval waktu lima (5) tahun. Pengujian dalam penelitian ini dilakukan dengan model korelasi. Korelasi yang digunakan antara lain metode korelasi liner sederhana kemudian untuk dilakukan pengujian korelasi berganda. Korelasi berganda yaitu metode statistika yang digunakan untuk mengetahui pola umum hubungan yang mempengaruhi antara variabel. yang diterima kemudian dianalisis manual sesuai prosedur analisis dalam penelitian. Dimana dalam penelitian ini memiliki lebih dari satu variabel independen. Melihat dari hasil perhitungan diatas maka pengaruh Sumberdaya manusia (X1) terhadap pembentukan pola ruang (Y) mempunyai hasil korelasi sedang yaitu 0,421 dimana rhitung $<$ rtabel $=0,878$ pada taraf signifikansi alpha 0.05 maka $\mathrm{H} 0$ diterima dan $\mathrm{H} 1$ ditolak. Hal ini membuktikan bahwa peningkatan kualitas sumberdaya manusia (pegawai) tidak memiliki keterhubungan yang berati terhadap pembentukan pola ruang. Hasil analisis perhitungan korelasi pada bab IV menunjukkan bahwa implementasi kebijakan (X2) memiliki kerterhubungan yang sangat kuat terhadap pembentukan pola ruang(Y). Keberhasilan penerapan implementasi kebijakan pelayanan IMB maka semakin kuat pengaruhnya terhadap pembentukan pola ruang dimana rhitung = 0,9805 lebih besar dari $\mathrm{r}$ tabel $=0.878$ pada taraf signifikansi $5 \%$ dimana $\mathrm{H} 0$ dtolak dan $\mathrm{H} 1$ diterima. Hasil pengujian dan perhitungan analisis korelasi terhadap Variabel peningkatan Kualitas sumberdaya manusia(pegawai)(X1) dan Implementasi Kebijakan(X2) secara bersama-sama memiliki keterhubungan sangat kuat terhadap Pembentukan Pola ruang sebesar 0.9801. Dimana jika Rhitung lebih besar dari Rtabel sebesar 0,878, pada taraf signifikansi alpha adalah 0.05, maka H0 di tolak dan H1 diterima.
\end{abstract}

Kata Kunci : Kualitas SumberDaya Manusia; Implementasi Kebijakan; Pembentukan Pola Ruang

\begin{abstract}
This study aims to identify and analyze how the influence of the quality of human resources and the implementation of the policies of the PUPR Office of Bantaeng Regency together on the formation of spatial patterns in Bissappu District, Bantaeng Regency. The analytical method used in this study is testing the data obtained based on times series data or time to time based on data collected over a five (5) year time interval. Tests in this study were conducted with the correlation model. The correlation used includes a simple linear correlation method and then multiple correlation tests are carried out. Multiple correlation is a statistical method used to determine the general pattern of relationships that affect between variables. received is then analyzed manually according to the analytical procedures in the study. Where in this study has more than one independent variable. Looking at the results of the above calculation, the influence of human resources (X1) on the formation of spatial patterns $(Y)$ has a moderate correlation, namely 0.421 where rcount rtable $=0.878$ at a significance level of alpha 0.05 then $\mathrm{HO}$ is accepted and $\mathrm{HI}$ is rejected. This proves that improving the quality of human resources (employees) does not have a significant relationship with the formation of spatial patterns. The results of the analysis of correlation calculations in chapter IV show that policy implementation (X2) has a very strong relationship with the formation of spatial patterns $(Y)$. The successful implementation of the IMB service policy implementation, the stronger the influence on
\end{abstract}


the formation of spatial patterns where rcount $=0.9805$ is greater than rtable $=0.878$ at a significance level of $5 \%$ where $H O$ is rejected and $\mathrm{HI}$ is accepted. The results of testing and calculation of correlation analysis on the Variable of improving the quality of human resources (employees) (X1) and Policy Implementation (X2) together have a very strong relationship to the formation of spatial patterns of 0.9801. Where if Rcount is greater than Rtable of 0.878, at the alpha significance level is 0.05 , then $\mathrm{HO}$ is rejected and $\mathrm{Hl}$ is accepted.

Keywords: Quality of Human Resources; Policy Implementation; Spatial Pattern Formation

\section{Pendahuluan}

Sumberdaya manusia mempunyai peranan yang besar baik dalam suatu organisasi, perusahaan dan institusi untuk mencapai suatu tujuan. Dalam suatu organisasi pemerintahan, diperlukan sumberdaya manusia yang mempunyai potensi, kemampuan sehingga organisasi tersebut dapat berjalan dengan lancar bahkan dapat mencapai suatu keberhasilan.

Perkembangan teknologi diberbagai sektor menuntut manusia untuk lebih mengembangkan kompetensi diri dengan mengikuti berbagai pelatihan, diklat maupun bimbingan teknis sehingga dapat memanfaatkan programprogram aplikasi baik pada dunia usaha maupun dalam organisasi pemerintahan. Selain itu perlunya peran pimpinan dalam melihat potensi karyawan maupun pegawai dalam perusahaan atau organisasi pemerintahan untuk dapat lebih memberikan peluang kepada karyawan maupun pegawai untuk mengikuti pelatihan dan diklat demi kebutuhan perusahaan/organisasi pemerintahan. Pelatihan dan diklat ini sangatlah diperlukan pada pegawai yang bekerja pada bidang pelayanan masyarakat pada berbagai sektor pelayanan. Salah satu diantaranya adalah pelayanan perizinan dalam mendirikan bangunan.

Izin mendirikan bangunan dalam suatu daerah atau wilayah yang dikeluarkan oleh pemerintah adalah merupakan suatu dasar hukum dalam mendirikan suatu bangunan. Dengan berpedoman pada Rencana Tata Ruang Wilayah Kabupaten/Kota, pemerintah membantu masyarakat dalam hal penetapan peruntukan ruang lokasi yang akan dibangun. Oleh karena itu menjadi kewajiban setiap orang atau Badan Usaha yang akan melakukan pembangunan untuk mengajukan permohonan kepada Dinas terkait yaitu Dinas Perizinan yang terdapat dalam suatu wilayah. Disisi lain, suatu bangunan sangat diperlukan oleh manusia sebagai tempat untuk melakukan kegiatan, usaha dan sebagai tempat perlindungan setelah beraktivitas dilapangan. Pembangunan rumah tinggal, Ruko, Rukan, industri dan perdagangan jasa setiap tahun mengalami pertambahan di setiap wilayah pada suatu daerah hal ini dikarenakan adanya perkembangan pusat kota dalam daerah tersebut, yang membutuhkan bangunan sebagai fasilitas untuk melaksanakan kegiatan ataupun sebagai rumah tinggal. Sementara Kapasitas lahan sangat terbatas sehingga banyak terjadi alih fungsi lahan dari lahan pertanian menjadi lahan non pertanian. Kebutuhan akan lahan akan terus meningkat sejalan dengan meningkatnya pertumbuhan penduduk, pertumbuhan ekonomi dan pengembangan wilayah yang merupakan bentuk aktivitas penduduk dalam pembangunan seperti dikatakan oleh (Maurinus Roy A C et.all, 2017).

Pemanfaatan lahan yang semula berfungsi untuk sawah, berangsur-angsur berubah menjadi multifungsi pemanfaatan. Implikasi alih fungsi lahan pertanian yang tidak terkendali dapat mengancam kapasitas penyediaan pangan, dan bahkan dalam jangka panjang dapat menimbulkan kerugian sosial (Muhammad Iqbal dan Sumaryanto : 2007). Rencana tata ruang yang dibuat pemerintah Indonesia harus sesuai dan searah dengan satu sama lain. Struktur sistem perencanaan tata ruang mengalokasikan sejumlah besar otoritas pengambilan keputusan kepada pemerintah baik tingkat pusat, provinsi dan kabupaten/kota untuk melaksanakan fungsi perencanaan tata ruang di daerahnya, termasuk otorisasi tingkat kabupaten/kota untuk mengalokasikan izin untuk kegiatan pemanfaatan lahan. Di Kota makassar pemanfaatan lahan pertanian berangsur-angsur berkurang akibat alihfungsi lahan yang tak dapat di hindarkan lagi. Alihfungsi lahan dari lahan pertanian menjadi non pertanian seperti pembangunan Ruko, Rumah tinggal, Perumahan, Rukan, bahkan industri. Hal ini dikarenakan tuntutan perkembangan kota yang membutuhkan fasilitas untuk memenuhi kebutuhan hidup. Pemerintah Propinsi berupaya dalam pelaksanaan pembangunan mengacu pada rencana tata ruang agar sesuai dengan peruntukan dalam rencana pola ruang. Namun masih banyak dijumpai adalah pembangunan yang tidak sesuai dengan peruntukan alokasi ruang. Pembentukan pola ruang yang dilakukan masyarakat dalam pembangunan mengikuti luas lahan yang mereka miliki tanpa memperhatikan adanya pemberlakuan rencana pola ruang yang perlu dipedomani dalam melakukan pembangunan terutama pada pembangunan rumah tinggal.

Di Kabupaten Bantaeng masih banyak di jumpai pembangunan rumah yang tidak sesuai dengan peruntukan ruang. Pembangunan rumah tinggal setiap tahun menjadi suatu kebutuhan utama dikarenakan kebutuhan untuk hidup dan penghidupan. Lahan pertanian basah yaitu sawah di kabupaten Bantaeng umumnya berada di wilayah perkotaan Bantaeng yaitu sebahagian di Kecamatan Bantaeng, sebahagian di Kecamatan Bissappu dan sebahagian di Kecamatan Pa'jukukang. Hal ini yang sering menimbulkan permasalahan pada perizinan dikarenakan lahan pertanian dialihfungsikan menjadi rumah tinggal, Ruko, Perhotelan, Restoran, Warung makan dan kafe. Permasalahan sering terjadi pada saat pengurusan izin mendirikan bangunan dikarenakan oleh perubahan peruntukan lahan sehingga beberapa persyaratan teknis yang harus di penuhi sebagai persyaratan peruntukan ruang yang ditetapkan dalam Rencana Pola Ruang RTRW Kabupaten Bantaeng. Sementara Rencana Tata Ruang Wilayah dengan skala 1:50.000 hanya mampu dalam penetapan Peruntukan Kawasan dalam suatu wilayah Kecamatan pada suatu rencana pembangunan dalam suatu wilayah. Selain itu permasalahan didalam birokrasi pemerintahan sendiri dalam hal perizinan adalah pengurusan Izin Mendirikan Bangunan yang panjang dan lama pada Dinas Perizinan yaitu Dinas Penanaman Modal dan Perizinan Terpadu Satu 
Pintu Kabupaten Bantaeng. Disisi lain efektifitas waktu yang ditetapkan tidak berbanding dengan implementasi penyelesaian rekomendasi Izin. Hal ini dikarenakan belum didukung oleh Sumberdaya manusia yang memiliki kompetensi di bidang penataan ruang, yang memahami perencanaan ruang sehingga dapat memberikan pemahaman kepada setiap orang, badan usaha dan organisasi dalam pengurusan Izin terutama pengurusan Izin mendirikan bangunan. Proses administrasi yang berjalan masih melibatkan organisasi perangkat daerah teknis terutama Dinas PU dan Penataan Ruang dimana salah satu bidang urusan yang mengurusi pelayanan pembangunan yaitu bidang Penataan ruang. Selain itu Sistem aplikasi yang di gunakan Online Single Submission (OSS) belum berjalan efektif yang dapat membantu penyelesaian proses permohonan perizinan di Kabupaten Bantaeng karena belum di lengkapi dengan regulasi yang lebih detail yaitu RDTR sehingga menyebabkan proses birokrasi yang panjang maka kebanyakan masyarakat lebih memilih membangun tanpa melakukan permohonan izin. Dinas PMPTSP melakukan kerjasama dengan beberapa organisasi perangkat daerah lainnya dalam penyelesaian proses perizinan. Diantaranya adalah Dinas PU dan Penataan ruang Kabupaten Bantaeng. Dinas PU dan Penataan Ruang merupakan salah satu Dinas yang melakukan teknis pelayanan perizinan mendirikan bangunan. Dinas PU dan Penataan ruang khususnya bidang penataan ruang dimana sumberdaya manusia yang mempunyai kompetensi penguasaan aplikasi Argis masih minim dalam hal kemampuannya melakukan pelayanan teknis kepada masyarakat yang berbasis ArGis dalam mengeluarkan rekomendasi. Hal ini yang menyebabkan sering terjadi perlambatan dalam mengeluarkan rekomendasi sebagai bentuk implementasi Dari dinas PU dan Penataan ruang. Disamping itu pula Peraturan Daerah Nomor 2 Tahun 2012 tentang Rencana Tata ruang wilayah Kabupaten Bantaeng belum dapat menentukan secara jelas peruntukan kawasan permukiman secara detail. Hal ini disebabkan oleh Skala 1:50.000 sehingga hanya mampu dalam penetapan suatu Kecamatan. Selain itu belum adanya Rencana Detail yang mampu menjawab dalam penentuan lokasi suatu kegiatan pembangunan. Kualitas sumberdaya manusia yang minim di Dinas PU dan Penataan Ruang minim pada kemampuan pengetahuan tentang pemetaan melalui aplikasi Ar-Gis. Implementasi Kebijakan Dinas PU dan Penataan Ruang dalam memberikan perhatian kepada pegawai untuk meningkatkan kualitas kinerja melalui pelatihan sesuai dengan bidangnya sampai saat ini belum dilakukan, pengembangan sumberdaya manusia masih nimin yang mengikuti pendidikan dan pelatihan sedangkan sebagaimana di ketahui bahwa peningkatan Kualitas sumber daya manusia merupakan faktor terpenting dalam keberhasilan sebuah organisasi, semakin meningkat kualitas sumber daya manusia semakin baik Prestasi kerja yang akan dihasilkan. Keberhasilan organisasi mencapai tujuannya sangat bergantung pada kualitas sumber daya manusianya. Untuk mencapai suatu kualitas kerja yang baik maka perlunya perhatian Pimpinan Unit kerja sebagai bentuk implementasi Kebijakan Dinas PU dan Penataan ruang dalam melihat akan hal ini. Menurut Hasibuan (2012: 10), mengemukakan bahwa: "Manajemen sumber daya manusia adalah ilmu dan seni mengatur hubungan dan peranan tenaga kerja agar efektif dan efisien membantu mewujudkan tujuan organisasi, pegawai, dan masyarakat".

Kurangnya sumberdaya manusia yang memiliki kompetensi aplikasi berbasis Ar-Gis dalam pelayanan di Dinas PUPR sehingga sisi pengendalian kurang terkontrol dengan baik, banyak penyimpangan-penyimpangan yang terjadi dimasyarakat dalam melakukan pembangunan terutama rumah tinggal. Penyimpangan di lapangan terlihat pembangunan tidak sesuai dengan peruntukan ruang, tidak sesuai dengan pembentukan pola ruang sebagaimana yang termuat dalam rencana pola ruang terhadap bangunan yang akan di bangun. Penerapan implementasi kebijakan belum sepenuhnya berjalan sesuai arahan rencana tata ruang mengakibatkan Pelanggaran terhadap garis sempadan jalan, sempadan sungai menyebabkan pengendalian pemanfaatan ruang tidak sesuai peruntukannya. Hal ini disebabkan oleh ketidakmampuan Sumber Daya Manusia dalam menyelesaikan permasalahan perizinan yang sesuai dengan Rencana pola ruang.

Melihat Permasalahan diatas maka peneliti perlu untuk meneliti pengaruh peningkatan kualitas sumber daya manusia dan Implementasi kebijakan Dinas PUPR terhadap pembentukan pola ruang agar sesuai dengan rencana pola ruang yang telah ditetapkan dalam RTRW Kabupaten Bantaeng sehingga penyelesaian permasalahan perizinan bangunan menjadi efektif dan terarah.

\section{Metode Penelitian}

\section{a. Jenis Penelitian}

Jenis penelitian yang akan digunakan oleh peneliti adalah jenis penelitian Kuantitatif dimana pada dasarnya menghasilkan hasil analisis dengan numerik (angka) yang akan diolah dengan metode statistik, yang selanjutnya akan menghasilkan signifikansi perbedaan dari hubungan antara variabel yang akan diteliti.

\section{b. Lokasi Penelitian}

Lokasi penelitian adalah tempat dimana penelitian dilakukan. Lokasi ini sangat penting dalam penelitian kuantitatif karena mempermudah peneliti melakukan objek dan tujuannya. Peneliti menetapkan lokasinya pada Dinas Pekerjaan Umum dan Penataan Ruang(PUPR) Kabupaten Bantaeng

\section{c. Populasi dan Sampel}

Populasi adalah wilayah yang terdiri atas objek atau subjek yang mempunyai kualitas dan karakteristik tertentu yang ditetapkan oleh peneliti untuk dipelajari dan kemudian ditarik kesimpulannya menurut sugiyono (2013). Populasi dalam penelitian ini yaitu jumlah pegawai berdasarkan tingkat pendidikan yang bertugas dalam melaksanakan pelayanan permohonan izin mendirikan bangunan di kecamatan pegawai yang di yang berdasarkan Data Time Series yaitu itu 5 Tahun populasi yang akan diteliti.

Berdasarkan teknik pengambilan sampel tersebut, diperoleh jumlah sampel (n) dari data Time Series setiap Tahun $\mathrm{n}=5$ selama periode tahun 2016 - tahun 2020, berdasarkan populasi dalam penelitian ini yaitu jumlah pegawai berdasarkan tingkat pendidikan, maka pada teknik pengambilan sampel ini peneliti mengambil sampel sebagian atau yang mewakili pegawai secara keseluruhan yang dianggap dapat melaksanakan tugas dan tanggungjawab yang diberikan. Diasumsikan bahwa setiap 
bidang mewakili 1-3 orang bertugas dalam melaksanakan pelayanan permohonan izin mendirikan bangunan di kecamatan Bissappu dan khusunya pada bidang penataan ruang peneliti mengambil sampel keseluruhan pegawai jumlah pegawai dimana bidang tersebut mempunyai tugas pokok dalam pelayanan perizinan dengan berdasarkan Data Time Series yaitu itu 5 Tahun yang akan diteliti.

\section{d. Jenis dan Sumber Data}

Peneliti melakukan pengambilan data yang bersumber dari data sekunder Dinas PU dan Penataan ruang yaitu data komposisi SDM berdasarkan tingkat pendidikan untuk mengukur sejauh mana pemahaman SDM(Pegawai) dalam memahami kebijakan Dinas PUPR dalam pelayanan pemberian rekomendasi terhadap pembentukan pola ruang permukiman di kecamatan Bissappu.

1. Data Pegawai Peningkatan kualitas SDM pada Dinas PUPR dari tingkat pendidikan pada Dinas PU dan Penataan Ruang mulai tahun 2016-2020.

2. Data Rekomendasi bangunan Izin mendirikan bangunan yang telah dikeluarkan oleh Dinas PUPR selama 5 Tahun yaitu dimulai dari tahun 2016-2020 di Kecamatan Bissappu.

3. Data Pemberian rekomendasi Izin mendirikan rumah tinggal pada Pembentukan Pola Ruang dimana pola pembangunan pemukiman masyarakat(rumah tinggal) yang pada umumnya mengikuti jalur jalan yang ada di Kecamatan Bissappu Tahun 2016-2020.

4. Pada penelitian ini data yang digunakan adalah data sekunder berupa Data Time Series dengan jangka waktu tahun 2016-2020 selama 5 Tahun. Data ini diambil melihat dasar perencanaan tata ruang yaitu RTRW dapat di Revisi Minimal Sekali Dalam 5 Tahun.

\section{e. Variabel Penelitian}

Variabel adalah suatu atribut atau sifat atau nilai dari orang, obyek atau kegiatan yang mempunyai variasi tertentu yang ditetapkan oleh peneliti untuk dipelajari kemudian menarik kesimpulan(Sugiyono; 2013:38)

1. Variabel Independen

Variabel independen/Variabel bebas sering disebut variabel stimulus, predictor, antecedent adalah yang mempengaruhi atau yang menjadi sebab perubahannya atau timbulnya variabel dependen/terikat (sugiyono:2013:63).

a. Sumberdaya Manusia $\left(\mathrm{X}_{1}\right)$

Variabel independen atau variabel bebas yang dimaksudkan adalah Sumberdaya manusia. Sumberdaya manusia $\left(\mathrm{X}_{1}\right)$ dimaksudkan adalah dilihat antara lain :

1) Pendidikan

yang dimaksudkan adalah Sumberdaya manusia yaitu Pegawai yang bekerja pada Dinas PUPR memiliki latarbelakang pendidikan yang berbeda beda mulai dari tingkat Pendidikan Dasar yaitu Sekolah Dasar sampai Pendidikan tingkat S2 Pasca Sarjana. Dengan latar belakang pendidikan yang berbeda-beda tentunya yang menjadi fokus SDM yang di teliti adalah SDM yang paham tentang RTRW sehingga dapat memberikan pertimbangan sebelum dikeluarkannya kebijakan Rekomendasi dari Dinas PUPR tentang Izin mendirikan Bangunan yang selanjutnya akan di proses ke Dinas PMPTSP untuk d terbitkan Sertifikat IMB(Izin
Mendirikan Bangunan).

2) Pelatihan

Dimaksudkan bahwa Setiap pegawai di Dinas PUPR senantiasa diharapkan dapat mengembangkan/meningkatkan kualitas SDMnya melalui berbagai pelatihan, bimbingan Teknis,dan Ketrampilan seperti pelatihan/bimbingan teknis tentang Aplikasi berbasis IT atau aplikasi Peta Berbasis GIS, ketrampilan yaitu trampil dan menguasai alat baik untuk pengukuran dan GPS sebagai sarana dan prasarana sehingga dapat memudahkan penyelesaikan perkerjaan dengan cepat.

b. Implementasi Kebijakan (X2)

Pada variabel kedua yaitu Implementasi kebijakan dimaksudkan implementasi kebijakan sangat penting dalam penyelesaian suatu kegiatan atau pelayanan. Kkeberhasilan dan kegagalan dalam mengimplementasikan dan mengeluarkan rekomendasi kebijakan yaitu pemberian rekomendasi Izin mendirikan bangunan pada setiap bangunan didukung oleh beberapa hal antara lain :

1) Komunikasi, dimana komunikasi sangat diperlukan dalam pekerjaan baik terhadap Pimpinan, maupun sesama rekan kerja, atau bawahan dan lingkungan, antara lain : Dalam hal ini peneliti kecenderungan melihat:

a. ada kejelasan dalam komunikasi dengan pimpinan agar pekerjaan yang dilakukan sesuai arahan dan petunjuk pimpinan khususnya pelayanan.

b. Ada kejujuran dalam komunikasi antara (Pegawai) dengan pimpinan maupun rekan kerja karena dalam bekerja untuk mendapatkan informasi. Sehingga ada kepercayaan baik dari pimpinan maupun rekan kerja.

2) Sumberdaya

Sumberdaya adalah manusia yaitu pegawai dan sarana dan prasarana pendukung dalam pekerjaa. Hal ini dikarenakan bahwa pegawai sebagai penggerak dalam berkerja dana perangkat merupakan alat pendukung dalam bekerja sebagai alat media informasi yang dapat menghubungkan komunikasi baik antar bidang maupun di luar antar Organisasi perangkat daerah lainnya. Peralatan dalam bekerja seperti fasilitas Internet, sebagai sarana teknologi dan informasi untuk membantu dalam bekerja selain itu peralatan perangkat komputer meja dan kursi untuk memberikan rasa nyaman dan tenang dalam bekerja.

3) Disposisi

Disposisi dimaksudkan adalah penyampaian secara singkat yang ditujukan kepada pegawai yang akan ditugaskan pada suatu pekerjaan atau kegiatan. Disposisi yang dikeluarkan oleh kepala Dinas PUPR. Disposisi yang dikeluarkan kepada pegawai yang dituju dengan maksud dan tujuan pegawai ter\$but dapat menjalankan tugasnya dengan penuh 
tanggungjawab. Sehingga hasil yang diterima oleh kepala dinas adalah berupa rekomendasi yang siap untuk di keluarkan. Dalam hal ini yang dimaksud adalah rekomendasi izin mendirikan bangunan.

4) Struktur Birokrasi

Struktur birokrasi dimaksudkan bahwa memiliki Standar Operasional Prosedur dalam pelaksanaan pekerjaan. Dengan adanya SOP maka pimpinan dalam memberikan disposisi kepada pegawai terarah kepada tugas pokok pegawai terutama dalam pelayanan pengurusan rekomendasi perizinan. Dam masing- masing bidang dalam yang terkait dalam perijinan mempunyai keterwakilan pegawai yang dapat menyelesaikan pekerjaan.

2. Variabel Dependen (Terikat)

Variabel Dependen/variabel terikat sering disebut output, kriteria, konsekuen adalah variabel yang dipengaruhi atau yang menjadi akibat, karena adanya variabel bebas(Sugiyono :2013 :63). Variabel dependen dalam penelitian ini adalah Pembentukan Pola Ruang (Y).

Pembentukan Pola ruang yang dimaksudkan adalah bentukan pola permukiman masyarakat (rumah tinggal) di Kecamatan Bissappu pada umumnya secara alami mengikuti sepanjang kiri dan kanan jalur jalan. oleh karenanya diharapkan dalam pembangunannya dengan tetap memperhatikan sempadan bangunan dan jalan sesuai arahan Rencana Pola ruang. Permukiman yang terdapat di Kecamatan Bissappu pada umumnya berada pada Lahan Pertanian basah (sawah). Sebagian bentukan pola pemukiman masyarakat

\section{f. Teknik Analisis}

Metode analisis yang digunakan dalam penelitian ini yaitu pengujian data-data yang diperoleh berdasarkan data times series atau waktu ke waktu berdasarkan data yang dikumpulkan selama interval waktu lima (5) tahun.

Pengujian dalam penelitian ini dilakukan dengan model korelasi. Korelasi yang digunakan antara lain metode korelasi liner sederhana kemudian untuk dilakukan pengujian korelasi berganda. Korelasi berganda yaitu metode statistika yang digunakan untuk mengetahui pola umum hubungan yang mempengaruhi antara variabel. yang diterima kemudian dianalisis manual sesuai prosedur analisis dalam penelitian. Dimana dalam penelitian ini memiliki lebih dari satu variabel independen.

\section{Hasil dan Pembahasan}

\section{Variable Penelitan}

Hasil penelitian ini peneliti akan menguraikan secara singkat kondisi dari masing-masing variabel X1, X2 dan Y antara lain :

\section{a. Sumberdaya Manusia (Variabel X1)}

Dinas PU dan Penataan Ruang pada tahun 2016 memiliki SDM pegawai berjumlah 89 orang. Dari 89 orang ini dimana memiliki latar belakang pendidikan yang berbeda-beda. Mulai dari tingkat SD, SMP/SLTP, Paket C, SMA, STM, SMEA dan SMK, Diploma III, Tingkat Pendidikan S1 dengan berbagai jurusan keilmuan dan pendidikan Tingkat Pasca Sarjana (S2) juga dari berbagai jurusan keilmuan. Pada umumnya adalah berlatar belakang pendidikan Sarjana Teknik dari beberapa jurusan. Secara struktur organisasi Dinas PUPR terdiri dari Sekretariat, Bagian Keuangan, dan Program, Bidang binamarga, Pengairan, Perumahan dan Permukiman perkotaan dan perdesaan, bidang tata ruang, dan dua uptd ipal dan rusunawa. Pegawai tersebut tersebar pada bidang di beberapa bidang pekerjaan. Selama lima tahun terakhir tahun 2016- 2020, disamping terjadi mutasi, masa pensiun dan perpindahan pegawai sehingga jumlah pegawai sampai pada tahun 2020 berkurang menjadi 62 orang secara keseluruhan.

Dari jumlah pegawai yang setiap tahun mengalami penurunan diakibatkan perpindahan dan mutasi serta pensiun namun Kepala Dinas tetap selalu berusaha untuk memberikan edukasi kepada pegawai agar tidak tertinggal informasi dan teknologi yang semakin hari membuat setiap pegawai untuk belajar sehingga tidak tertinggal informasi, baik informasi teknis maupun informasi tentang pelayanan kepada masyarakat. Walaupun terjadi penurunan jumlah pegawai namun dari sisi pelayanan ada keterwakilan yang bekerja untuk melayani masyarakat khususnya dalam pelayanan permohonan izin mendirikan bangunan(IMB) atau saat ini lebih dikenal dengan persetujuan bangunan gedung(PBG). Dimana pelayanan permohonan mulai tahun 2021 menggunakan sarana aplikasi SIMBG(sistem Informasi Memdirikan Bangunan Gedung) sehingga pelayanan diharapkan dapat lebih cepat. Diantara pilihan SDM dari bidang maka khusus untuk bidang penataan ruang adalah keseluruhan pegawai bidang tata ruang karena merupakan tugas pokok dalam pelayanan perizinan. Keterbatasan jumlah pegawai dengan latarbelakang pendidikan maka dalam pelayanan teknis masih berbasis manual walaupun sistem sudah dilaksanakan. Keterbatasan beberapa pegawai yang belum dapat memahami akan aplikasi sehingga terjadi perlambatan pelayanan. Secara umum tidak ada formasi untuk penerimaan pegawai khususnya bidang perencanaan wilayah dan kota walaupun usulan Dinas selalu dilakukan. Sehingga untuk pekerjaan yang berbasis aplikasi Gis menggunakan tenaga honorer yang masih baru jurusan PWK untuk membantu penyelesaian pekerjaan pelayanan teknis perizinan. Untuk jelasnya dapat dilihat pada Tabel 3.1. dan tabel 3.2. dan tabel 3.3 pada bab 3 dan pada lampiran.

Peneliti menguraikan isi tabel 3.3. dimana bahwa setiap tahun dari tahun 2016 -2020 ketewakilan dan bidang yang bekerjasama dalam proses pelayanan perizinan secara bersama-sama walaupun setiap bidang berbeda beda tingkat pemahaman mereka tentang keberadaan aturan RTRW. Dimana RTRW masih menjadi acuan dasar dalam pengeluarkan rekomendasi perizinan membangun Di Dinas PUPR. mulai dari UPTD IPAL keterwakilan 1 orang yaitu kepala UPTD, dimana juga selaku perwakilan dalam pengambilam pertimbangan tentang perlunya keberadaan IPAL pada pemukiman masyarakat, selanjutnya bidang penataan ruang dimana sudah menjadi tugas pokok sehingga mulai dari staf sampai kepala bidang melakukan pekerjaan pelayanan baik teknis maupun administrasi yaitu retribusi pembayaran IMB. Namun mulai dari tahun 2016 sampai 2020 terjadi penurunan pegawai, ada yagng berpindah tugas keluar daerah, dan mutasi. Namun pelayanan proses rekomendasi tetap berjalan dengan baik, Selanjutnya pada bidang ciptakarya, keterwakilan 
berjumlah 3 orang, mulai dari kepala bidang, kepala seksi bangunan gedung dan staf operator yang dapat mengoperasikan sistem aplikasi keluarnya Sertifikat Laik fungsi yang merupkan persyaratan bangunan gedung.

Dari tahun 2016-2020 sempat mengalami mutasi tetapi kembali lagi bertugas pada bidang ciptakarya sehingga pelayanan perizinan SLF berjalan kembali dengan baik. Selanjutnya bidang Pengairan atau Sumber daya air dimana keterwakilan 2-3 orang, mulai dari Kepala bidang, dan kepala seksi. Terjadi mutasi tempat bekerja sehingga pada tahun 2020 berkurang menjadi 2 orang sampai sekarang yang menangani perizinan dari sisi pertimbangan persyaratan pada zona sempadan sungai. Bidang binamarga atau bidang Jalan dan jembatan dimana keterwakilan 1-2 orang yaitu kepala Bidang dan kepala seksi. Inipun terjadi mutasi namun berganti pegawai dalam penempatan jadi tetap keterwakilan 2 orang yaitu kepala bidang dan kepala seksi yang paham dalam mengeluarkan pertimbangan zona sempadan jalan yang searah dengan arahan RTRW Kabupaten Bantaeng dan yang terakhir selaku pengambil kebijakan sebelum dikeluarkannya rekomendasi IMB diperiksa dan di paraf oleh sekretaris Dinas sebelum ditandatangani oleh Kepala Dinas. Keterwakilan pegawai ini yang peneliti jadikan dalam perhitungan statistik korelasi untuk melihat apakah ada pengaruh SDM terhadap pembentukan pola ruang di Kecamatan Bissappu.

\section{b. Implementasi Kebijakan Variabel X2)}

Implementasi kebijakan berupa rekomendasi perizinan mendirikan bangunan uang di keluarkan Dinas PU dan Penatan ruang adalah berdasarkan dari beberapa indikator yang di jalankan atau dilaksanakan selama ini di Dinas PU dan Penataan ruang. Ketika berkas telah di periksa dari bidang lain maka Bidang penataan ruang memerika kembali secara administrasi kelengkapan kemudian melanjutkan sesuai SOP yaitu ke sektretaris dinas untuk di periksa kembali dan di paraf dan selanjutnya kepala Dinas menandatangani rekomendasi izin mendirikan bangunan untuk dilanjutkan ke dinas perizinan yaitu dinas PMPTSP sebagai Dinas yang mengeluarkan Sertifikat izin mendirikan bangunan atau persetujuan bangunan gedung yang diterima oleh pemohon pada Dinas PMPTSP (Penanaman Modal dan Pelayanan Terpadu Satu Pintu). Pada penelitian ini peneliti fokus pada pemukiman rumah tinggal. .Implementasi Kebijakan Rekomendasi Dinas PU dan Penataan ruang ada bangunan rumah tinggal di Kecamatan Bissappu yang keluar sejak tahun 2016 sampai dengan tahun 2020 dapat dilihat pada tabel berikut :

Tabel 1. Rekapitulasi Jumlah Bangunan yang Ber-IMB di Kecamatan Bissappu Kab. Bantaeng Tahun 2016-2020

\begin{tabular}{lcc}
\hline No & Tahun & $\begin{array}{c}\text { Bangunan Rumah Tinggal Ber- } \\
\text { IMB (Unit) }\end{array}$ \\
\hline 1 & 2016 & 107 \\
2 & 2017 & 59 \\
3 & 2018 & 61 \\
4 & 2019 & 45 \\
5 & 2020 & 32 \\
\hline & Jumlah & 304 \\
\hline
\end{tabular}

Sumber : Hasil olah Data rekapituasi Bangunan Rumah tinggal Ber-IMB Bidang Penataan ruang Dinas PUPR Tahun 2021

Pada tabel diatas dari tahun 2016 -2020 adalah jumlah bangunan di Kecamatan Bissappu yang telah mendapat rekomendasi IMB dan telah terbit Sertifikat IMB pada Dinas PMPTSP. Jumlah bangunan tersebut diantaranya adalah bangunan, rumah tinggal. Uraian rincian data tersebut kami sajikan dalam lampiran. Melihat tabel tersebut menunjukkan bahwa masih kurangnya masyarakat yang berkeinginan untuk mengurus perizinan pada Dinas PMPTSP. Masih banyak yang membangun tanpa ada mengurus. Dinas PUPR sering melakukan teguran baik lisan maupun tertulis namun masih banyak masyarakat yang belum sadar akan pentingnya arturan dalam membangun. Tabel ini yang dijadikan peneliti untuk menghitung secara statistik pengaruh Implementasi Kebijakan terhadap pembentukan pola ruang di Kecamatan Bissappu.

\section{c. Pembentukan Pola Ruang}

Pembentukan pola pemukiman masyarakat di Kecamatan Bissappu umumnya adalah mengikuti sepanjang kiri dan kanan jalan. Dimana pada perkotaan Kecamatan Bissappu merupakan Lahan pertanian sawah yang subur sehingga perubahan peruntukan lahan pertanian menjadi rumah tinggal selalu menjadi persoalan untuk mendapatkan kesesuaian ruang karena harus melalui pertimbangan teknis Dinas Pertanian bahwa lahan pertanian tersebut dapat di alihfungsikan menjadi rumah tinggal ataukah tidak. Ada pula pola pemukiman yang memusat berada pada pusat kegiatan ekonomi, sehingga banyak pemukiman masyarakat berada di sekitar pusat kegiatan perekonomian tersebut.

Peneliti dalam hal ini mengambil data khususnya Rekapitulasi data bangunan rumah tinggal yang telah berizin mendirikan bangunan di Kecamatan bissappu Dari Tahun 2016-2020. Maksudnya selain pola ruangnya mengikuti jalur jalan namun tetap memperhatikan arahan zonasi dalam RTRW Kabupaten Bantaeng. Adapun data tersebut disajikan dalam Tabel berikut ;

Tabel. 2 Rekapitulasi Jumlah Bangunan Rumah Tinggal

yang Ber-IMB di Kecamatan Bissappu Kabupaten Bantaeng Tahun 2016-2020

\begin{tabular}{ccc}
\hline No & Tahun & $\begin{array}{c}\text { Bangunan rumah tinggal Ber-IMB } \\
\text { (Unit) }\end{array}$ \\
\hline 1 & 2016 & 45 \\
2 & 2017 & 20 \\
3 & 2018 & 15 \\
4 & 2019 & 9 \\
5 & 2020 & 7 \\
\hline & Jumlah & 96 \\
\hline
\end{tabular}

Sumber : Hasil olah Data Bangunan Rumah Ber-IMB Bidang Penataan ruang Dinas PUPR Tahun 2021

Melihat hasil data tersebut jumalah bangunan rumah tinggal dari tahun 2016 -2020 menunjukkan bahwa masih minimnya masyarakat yang mengajukan permohonan izin mendirikan bangunan, apalagi pada masa pandemi awal tahun 2020 lalu mengalami penurunan dari tahun 2019 dari jumlah bangunan rumah tinggal sebesar 9 unit bangunan, berkurang pada menjadi 7 unit di tahun 2020. Selain itu kelemahan penyajian data dalam bentuk peta adalah karena selama ini pada pengurusan IMB petugas dilapangan tidak dilengkapi dengan alat GPS untuk pengambilan koordinat setiap bangunan, selain itu pegawai pada bidang penataan ruang belum ada yang menguasai aplikasi Peta berbasis Argis. Sehingga kesulitan dalam penyajian data. Berikut ini akan disajikan peta permukiman di Kecamatan Bissappu. 


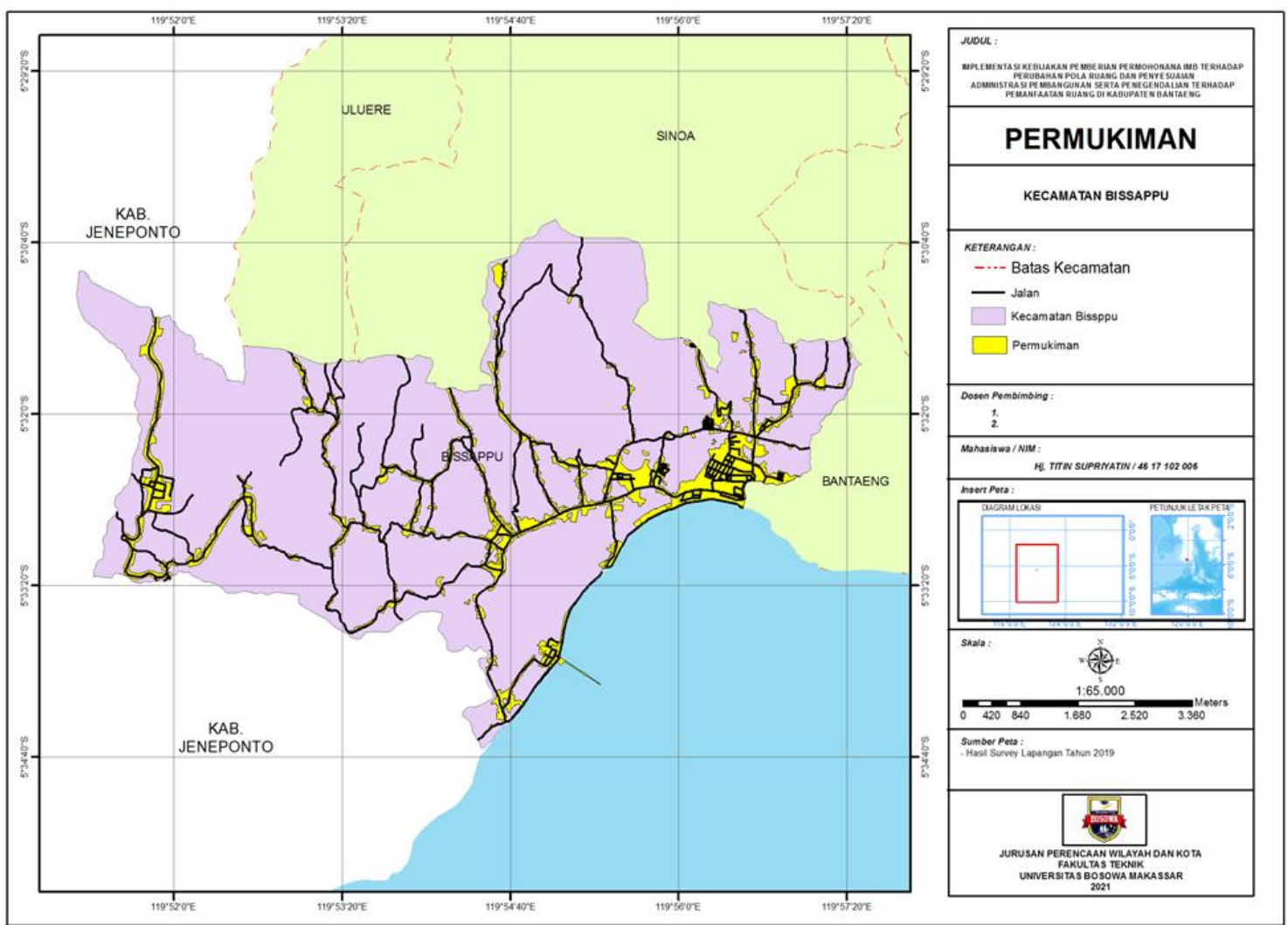

Gambar 1. Peta Pemukiman diKecamatan Bissappu Kabupaten Bantaeng Tahun 2019 Sumber Peta: Peta survey Permukiman Tahun 2019 berdasarkan Peta RDTR Kawasan Perkotaan Bissappu Tahun 2015-2016

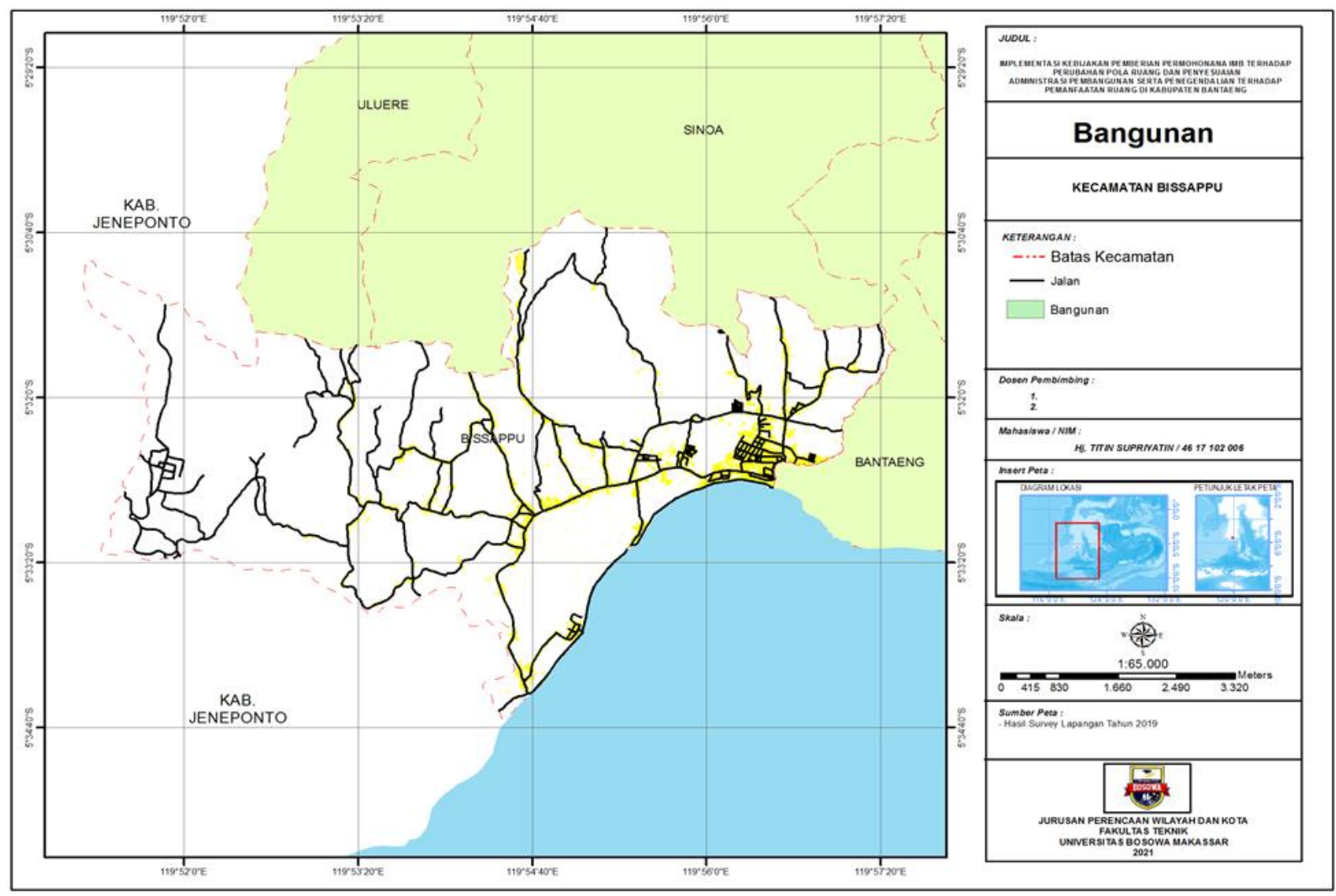

Gambar 2. Peta Bangunan di Kecamatan Bissappu Kabupaten Bantaeng Tahun 2019 Sumber Peta: Peta survey Bangunan Tahun 2019 berdasarkan Peta RDTR Kawasan Perkotaan Bissappu Tahun 2015-2016 
Dari uraian masing-masing variabel diatas maka peneliti akan menganalisis secara kuantitatif secara statistik dengan menggunakan metode analisis korelasi secara manual untuk melihat pengaruh variabel sumberdaya manusia $\left(X_{1}\right)$ terhadap variabel Pembentukan pola ruang (Y) implementasi Kebijakan $\left(\mathrm{X}_{2}\right)$, terhadap Pembentukan Pola ruang (Y) dan pengaruh sumberdaya manusia (X1) dan implementasi Kebijakan (X2) secara bersama sama terhadap Pembentukan Pola ruang (Y).

Pengujian perhitungan secara manual menggunakan Excel dan dituangkan hasilnya dalam bentuk tabe. Berikut data masing-masing variabel sebagai berikut:

Tabel.3 Data Variabel sumberdaya manusia (X1), Implementasi Kebijakan (X2) Pembentukan Pola ruang (Y)

\begin{tabular}{cccc}
\hline Tahun & $\begin{array}{c}\text { Sumberdaya } \\
\text { manusia } \\
\text { (X1)dalam } \\
\text { (Orang) }\end{array}$ & $\begin{array}{c}\text { Implementasi } \\
\text { Kebijakan } \\
\text { (X2)dalam } \\
\text { (Unit) }\end{array}$ & $\begin{array}{c}\text { Pembentukan } \\
\text { Pola ruang } \\
\text { (Y).(bangunan } \\
\text { rumah tinggal) } \\
\text { dalam Unit }\end{array}$ \\
\hline 2016 & 20 & 107 & 45 \\
2017 & 21 & 59 & 20 \\
2018 & 19 & 61 & 15 \\
2019 & 20 & 45 & 9 \\
2020 & 18 & 32 & 7 \\
\hline Jumlah & 98 & 304 & 96 \\
\hline Sumber:
\end{tabular}

Hasil perhitungan excel yang di tuangkan kedalam format word dibawah ini dalam tabel berikut ;

Tabel 4. Hasil perhitungan $\mathrm{X} 1, \mathrm{X} 2$ terhadap $\mathrm{Y}$

\begin{tabular}{cccccccccc}
\hline $\begin{array}{c}\text { Tahun } \\
(\mathrm{n})\end{array}$ & $\mathrm{X}_{1}$ & $\mathrm{X}_{2}$ & $\mathrm{Y}$ & $\mathrm{X}_{1}{ }^{2}$ & $\mathrm{X}_{2}{ }^{2}$ & $\mathrm{Y}^{2}$ & $\mathrm{X}_{1} \mathrm{Y}$ & $\mathrm{X}_{2} \mathrm{Y}$ & $\mathrm{X}_{1} \mathrm{X}_{2}$ \\
\hline 2016 & 20 & 107 & 45 & 400 & 11449 & 2025 & 900 & 4815 & 2140 \\
2017 & 21 & 59 & 20 & 441 & 3481 & 400 & 420 & 1180 & 1239 \\
2018 & 19 & 61 & 15 & 361 & 3721 & 225 & 285 & 915 & 1159 \\
2019 & 20 & 45 & 9 & 400 & 2025 & 81 & 180 & 405 & 900 \\
2020 & 18 & 32 & 7 & 324 & 1024 & 49 & 126 & 224 & 544 \\
\hline$\sum$ & 98 & 304 & 96 & 1891 & 21700 & 2780 & 1911 & 7539 & 6014 \\
\hline
\end{tabular}

Sumber: Hasil Analisis, 2021

Keterangan :

$\begin{array}{lll}\sum X_{1} & = & 98 \\ \sum X_{2} & = & 304 \\ \sum Y & = & 96 \\ \sum X_{1}^{2} & = & 1926 \\ \sum X_{2}^{2} & = & 21700 \\ \sum Y^{2} & = & 2780 \\ \sum X_{1} Y & = & 1911 \\ \sum X_{2} Y & = & 7539 \\ \sum X_{1} X_{2} & = & 6014 \\ \left(\sum X_{1}\right)^{2} & = & 9604 \\ \left(\sum X_{2}\right)^{2} & = & 92416 \\ \left(\sum Y^{2}\right. & = & 9216\end{array}$

2. Pengujian Variabel $X_{1} \cdot X_{2}$ Dan Variabel $Y$ Menggunakan Korelasi Linier Sederhana

a. Pengujian Variabel $\mathbf{X}_{1}$ terhadap $\mathbf{Y}$

Pengujian ini dilakukan untuk mengetahui seberapa besar pengaruh antara variabel sumberdaya manusia $\left(X_{1}\right)$ terhadap Pembentukan Pola ruang $(\mathrm{Y})$

$$
r_{X_{1} Y}=\frac{n \sum X_{1} Y-\left(\sum X_{1}\right)\left(\sum Y\right)}{\sqrt{\left(n \sum X_{1}^{2}-\left(\sum X_{1}\right)^{2}\right)} \cdot \sqrt{\left(n \sum Y^{2}-\left(\sum Y\right)^{2}\right.}}
$$

Ket :

$x_{1}=$ Sumberdaya manusia $\begin{array}{ll}x_{2} & =\text { Implementasi Kebijakan } \\ y & =\text { Pembentukan Pola }\end{array}$

$$
\begin{aligned}
r_{X_{1} Y} & =\frac{5 \times 1911-(98)(96)}{\sqrt{(5 \times 1926-9604)} \cdot \sqrt{(5 \times 2780-9216)}} \\
r_{X_{1} Y} & =\frac{147}{\sqrt{26} \times \sqrt{4684}} \\
r_{X_{1} Y} & =\frac{147}{348,97} \\
r_{X_{1} Y} & =0,421
\end{aligned}
$$

Dimana bahwa :

$$
\begin{aligned}
\mathrm{r}_{\text {hitung }} & =0,421 \\
\mathrm{r}_{\text {tabel }} & = \\
\mathrm{db} & =\mathrm{N}-\mathrm{P}
\end{aligned}
$$

Keterangan :

$\mathrm{N} \quad=5$ tahun

$\mathrm{P} \quad=$ Pemberlakukan $\mathrm{X}_{1}$ dan $\mathrm{X}_{2}=2$

$\mathrm{db} \quad=5-2$

$\mathrm{db} \quad=3$

$\alpha \quad=0,05$

$\mathrm{r}_{\text {tabel }}=0,878$

Yang berarti bahwa:

Jika $\mathrm{r}_{\text {hitung }}=0,421<\mathrm{r}_{\text {tabel }}=0,878$ maka

$\mathrm{H} 0$ diterima dan $\mathrm{H} 1$ di tolak.

Dari hasil perhitungan diatas menunjukkan bahwa dalam perkembangan peningkatan kualitas sumberdaya manusia(pegawai) tidak memiliki keterhubungan dengan pembentukan pola ruang. Dimana berdasarkan skala likert tingkat keterhubungan kualitas sumberdaya manusia terhadap Pembentukan Pola ruang Pemukiman di Kecamatan Bissappu adalah sedang.

Hal ini menunjukkan bahwa semakin tinggi rendahnya bobot pendidikan sumberdaya manusia(pegawai) pada Dinas PU dan Penataan Ruang tidak memberikan keterhubungan yang berarti terhadap pembentukan pola ruang di Kecamatan Bissappu. Dan ternyata bahwa bisa saja pembentukan pola ruang di pengaruhi oleh variabel lain.

b. Pengujian variabel $X_{2}$ terhadap $Y$

$$
\begin{aligned}
r_{X_{2} Y} & =\frac{n \sum X_{2} Y-\left(\sum X_{2}\right)\left(\sum Y\right)}{\sqrt{\left(n \sum X_{2}^{2}-\left(\sum X_{2}\right)^{2}\right)} \cdot \sqrt{\left(n \sum Y^{2}-\left(\sum Y\right)^{2}\right.}} \\
r_{X_{2} Y} & =\frac{5 \times 7539-(304)(96)}{\sqrt{(5 \times 21700-92416)} \cdot \sqrt{(5 \times 2780-9216)}} \\
r_{X_{2} Y} & =\frac{8511}{\sqrt{16.084} \times \sqrt{4684}} \\
r_{X_{2} Y} & =\frac{8511}{8679,715} \\
r_{X_{2} Y} & =0.9805
\end{aligned}
$$

Dimana bahwa :

$$
\begin{array}{ll}
\mathrm{r}_{\text {hitung }} & =0,9805 \\
\mathrm{r}_{\text {tabel }} & = \\
\mathrm{db} & =\mathrm{N}-\mathrm{P}
\end{array}
$$

Keterangan :

$$
\begin{array}{ll}
\mathrm{N} & =5 \text { tahun } \\
\mathrm{P} & =\text { Pemberlakukan } \mathrm{X}_{1} \text { dan } \mathrm{X}_{2}=2 \\
\mathrm{db} & =5-2
\end{array}
$$




$$
\begin{array}{ll}
\mathrm{db} & =3 \\
\alpha & =0,05 \\
\mathrm{r}_{\text {tabel }} & =0,878
\end{array}
$$

Yang berarti bahwa

$$
\text { Jika } \mathrm{r}_{\text {hitung }}=0,9805>\mathrm{r}_{\text {tabel }} \quad=0,878
$$

maka $\mathrm{H} 0$ ditolak dan $\mathrm{H} 1$ di terima.

Dari hasil perhitungan menunjukkan bahwa dalam perkembangan Implementasi Kebijakan Dinas PU dan Penataan ruang memiliki keterhubungan dengan pembentukan pola ruang. Dimana berdasarkan skala likert tingkat keterhubungan implementasi Kebijakan Dinas PU dan Penataan Ruang terhadap Pembentukan Pola ruang Pemukiman di Kecamatan Bissappu adalah sangat kuat.

Hal ini menunjukkan bahwa keberhasilan Implementasi Kebijakan Dinas dalam pelayanan pemberian rekomendasi Izin mendirikan bangunan pada Dinas PU dan Penataan Ruang memberikan keterhubungan yang berarti terhadap pembentukan pola ruang pemukiman rumah tinggal di Kecamatan Bissappu.

\section{c. Pengujian Variabel X1 dan X2}

Dari hasil perhitungan menunjukkan bahwa dalam perkembangan peningkatan kualitas sumberdaya manusia tidak memiliki keterhubungan dengan Implementasi Kebijakan. Dimana berdasarkan skala likert tingkat keterhubungan peningkatan kualitas sumberdaya manusia terhadap Implementasi Kebijakan Dinas PUPR adalah sedang.

Hal ini membuktikan bahwa tinggi rendahnya tingkat pendidikan sumberdaya manusia(pegawai) pada Dinas PU dan Penataan Ruang tidak memberikan keterhubungan yang berarti terhadap implementasi Kebijakan pelayanan yang ditelah diterapkan di Dinas PUPR.

\section{d. Pengujian $R x_{1} x_{2} y$ Menggunakan Korelasi Berganda}

$$
R_{X_{1} X_{2} Y}=\sqrt{\frac{r^{2} x_{1} y+r^{2} x_{2} y-2 r x_{1} y \cdot r x_{2} y \cdot r x_{1} x_{2}}{1-r^{2} x_{1} x_{2}}}
$$

Keterangan:

$$
\begin{array}{lll}
R_{X_{1} X_{2} Y} & = & \text { Korelasi antara variabel sumberdaya manusia } \\
& \left(\mathrm{X}_{1}\right) \text { dan Implementasi } & \text { Kebijakan }\left(\mathrm{X}_{2}\right) \text { secara } \\
& \text { bersama-sama terhadap variabel Pembentukan } \\
& \text { Pola ruang }(\mathrm{Y}) & \\
R_{X_{1} Y} & =\quad \text { Korelasi antara } \mathrm{X}_{1} \text { dengan } \mathrm{Y} \\
R_{X_{2} Y} & = & \text { Korelasi antara } \mathrm{X}_{2} \text { dengan } \mathrm{Y} \\
R_{X_{1} X_{2}}= & \text { Korelasi antara } \mathrm{X}_{1} \text { dengan } \mathrm{X} 2
\end{array}
$$

$$
\begin{aligned}
& \operatorname{Ryx}_{1} x_{2} \\
& =\sqrt{\frac{(0,421)^{2}+(0,98)^{2}-2(0,421) \cdot(0,98) \cdot(429)}{1-(0,429)^{2}}} \\
& \operatorname{Ry}_{1} x_{2}
\end{aligned}
$$

\section{$\operatorname{Ry} x_{1} x_{2}=0,9801$}

$$
\begin{aligned}
& \text { Dimana bahwa : } \\
& \mathrm{r}_{\text {hitung }}=0,9801 \\
& \mathrm{r}_{\text {tabel }}= \\
& \mathrm{db} \quad=\mathrm{N}-\mathrm{P} \\
& \text { Keterangan : } \\
& \mathrm{N} \quad=5 \text { tahun }
\end{aligned}
$$

$$
\begin{array}{ll}
\mathrm{P} & =\text { Pemberlakukan } \mathrm{X}_{1} \text { dan } \mathrm{X}_{2}=2 \\
\mathrm{db} & =5-2 \\
\mathrm{db} & =3 \\
\alpha & =0,05 \\
\mathrm{r}_{\text {tabel }} & =0,878
\end{array}
$$

Yang berarti bahwa;

Jika $\mathrm{r}_{\text {hitung }}=0,9801>\mathrm{r}_{\text {tabel }}=0,878$

maka $\mathrm{H} 0$ ditolak dan $\mathrm{H} 1$ di terima.

Dari hasil perhitungan menunjukkan bahwa dalam Peningkatan kualitas sumberdaya manusia(pegawai) dan perkembangan Implementasi Kebijakan Dinas PU dan Penataan secara bersama-sama memiliki keterhubungan terhadap pembentukan pola ruang di Kecamatan Bissappu. Tingkat keterhubungan kualitas sumberdaya manusia dan implementasi Kebijakan Dinas PU dan Penataan Ruang terhadap Pembentukan Pola ruang Pemukiman di Kecamatan Bissappu adalah sangat kuat.

Hal ini menunjukkan bahwa keberhasilan Implementasi Kebijakan Dinas dalam pelayanan pemberian rekomendasi Izin mendirikan bangunan pada Dinas PU dan Penataan Ruang memberikan keterhubungan yang berarti terhadap pembentukan pola ruang pemukiman rumah tinggal di Kecamatan Bissappu.

\section{Pembahasan}

\section{a. Pengaruh Sumberdaya manusia $\left(X_{1}\right)$ terhadap Pembentukan Pola Ruang(Y)}

Berdasarkan hasil perhitungan secara statistik analisis korelasi linier dan berganda maka dapat dilihat bahwa Sumberdaya manusia(X1) pegawai dalam pelayanan memberikan pengaruh sedang yaitu 0,421 , terhadap pembentukan pola ruang( $\mathrm{Y})$ pemukiman rumah tinggal di kecamatan Bissappu. Hal ini membuktikan bahwa perkembangan sumberdaya manusia (pegawai) tidak memiliki keterhubungan terhadap pembentukan pola ruang. Semikin tinggi rendahnya tingkat pendidikan Sumberdaya manusia (SDM) pegawai tidak memberian pengaruh terhadap pembentukan pola ruang, tidak ada keterhubungan yang berarti. Ternyata pola ruang bisa saja terbentuk dari pengaruh variabel lain yang bukan sumberdaya manusia (pegawai). Hal ini menunjukkan bahwa Teori yang dikemukakan oleh Soekidjo Notoadmojo, 2009 tidak berlaku/ tidak dapat digunakan pada lokasi penelitian yang kami teliti.

\section{b. Pengaruh Implementasi Kebijakan $\left(\mathbf{X}_{2}\right)$ terhadap Pembentukan Pola Ruang (Y)}

Berdasarkan pada hasil perhitungan menggunakan analisis korelasi liner bahwa implementasi kebijakan(X2) berpengaruh sangat kuat terhadap pembentukan pola ruang(Y). Hal ini menunjukkan bahwa keberhasilan Implementasi kebijakan Dinas PU dan Penataan ruang didukung oleh beberapa indikator yaitu komunikasi pimpinan dan bawahan (pelaksana), kemudian kesiapan sumberdaya baik sumberdaya manusia maupun sarana dan prasarana penunjang, disposisi yang terarah dan struktur birokrasi yang cepat dalam melaksanakan tugas pelayanan maka akan meningkatkan jumlah bangunan rumah tinggal di kecamatan Bissappu, bentukan pola ruang pemukiman rumah tinggal semakin meningkat serta masyarakat yang membangun dan mengikuti arahan dalam rencana tata ruang.

Oleh karena itu, berdasarkan hasil penelitian membuktikan bahwa keberhasilan implementasi kebijakan 
Dinas PU dan Penataan Ruang yang didukung oleh beberapa indikator yang sangat mempengaruhi pembentukan pola ruang, Implementasi Kebijakan memiliki keterhubungan yang sangat kuat terhadap pembentukan pola ruang. Sehingga teori yang di kemukakan oleh George C. Edward III sebagaimana dideskripsikan oleh A.G. Subarsono' 2011 dapat di gunakan/berlaku pada lokasi penelitian yang kami teliti.

\section{c. Pengaruh Sumberdaya Manusia(X1) dan}

Implementasi Kebijakan (X2) secara bersamasama terhadap Pembentukan pola ruang (Y)

Dari hasil perhitungan analisis korelasi berganda dapat membuktikan bahwa pengaruh sumber daya manusia(X1) dan implementasi kebijakan (X2) secara bersama-sama maka akan memiliki keterhubungan yang sangat kuat terhadap pembentukan pola ruang (Y). Hal ini menunjukkan bahwa ternyata faktor yang paling berpengaruh terhadap pembentukan pola ruang adalah implementasi kebijakan. ini menunjukkan bahwa teori yang di kemukakan oleh George C. Edward III sebagaimana dideskripsikan oleh A.G. Subarsono' 2011. Dapat digunakan/ berlaku pada lokasi penelitian yang kami teliti.

d. Analisis Pengaruh Peningkatan Sumber Daya Manusia Pada Dinas PU dan Penataan Ruang Terhadap Pembentukan Pola Ruang

Melihat dari hasil perhitungan diatas maka pengaruh Sumberdaya manusia (X1) terhadap pembentukan pola ruang (Y) mempunyai hasil korelasi sedang yaitu 0,421 dimana rhitung $<$ rtabel $=0,878$ pada taraf signifikansi alpha 0.05 maka H0 diterima dan $\mathrm{H} 1$ ditolak Hal ini membuktikan bahwa peningkatan kualitas sumberdaya manusia (pegawai) tidak memiliki keterhubungan yang berati terhadap pembentukan pola ruang. Berarti Teori yang dikemukakan oleh Sikidjo notoatmodjo tidak dapat di gunakan pada lokasi penelitan yang kami teliti.

\section{e. Analisis Implementasi kebijakan Dinas PUPR terhadap pembentukan Pola Ruang}

Hasil analisis perhitungan korelasi diatas menunjukkan bahwa implementasi kebijakan (X2) memiliki kerterhubungan yang sangat kuat terhadap pembentukan pola ruang(Y). Keberhasilan penerapan implementasi kebijakan pelayanan IMB maka semakin kuat pengaruhnya terhadap pembentukan pola ruang dimana rhitung $=0,9805$ lebih besar dari $r$ tabel $=0.878$ pada taraf signifikansi $5 \%$ dimana $\mathrm{H} 0$ dtolak dan $\mathrm{H} 1$ diterima. Berarti Teori yang dikemukakan Goerge Edward dalam subarsono dapat digunakan pada lokasi penelitian.

\section{f. Analisis Pengaruh antara Peningkatan \\ Sumberdaya Manusia dan Implementasi \\ Kebijakan Dinas PUPR Kabupaten Bantaeng Secara Bersama-Sama Terhadap Pembentukan Pola Ruang \\ Hasil pengujian dan perhitungan analisis korelasi} terhadap peningkatan Sumberdaya manusia (X1) dengan implementasi kebijakan (X2) di mana RX1Y, RX2Y berpengaruh sangat kuat secara simultan terhadap RX1X2Y. Variabel peningkatan Kualitas sumberdaya manusia (pegawai) (X1) dan Implementasi Kebijakan (X2) secara bersama-sama memiliki keterhubungan sangat kuat terhadap Pembentukan Pola ruang sebesar 0.9801. Dimana jika Rhitung lebih besar dari Rtabel sebesar 0,878, pada taraf signifikansi alpha adalah 0.05 , maka H0 di tolak dan H1 diterima. Ini menunjukkan keberartian hubungan yang sangant kuat. Berarti Teori yang dikemukakan oleh
Soekidjo Notoatmodjo dan George C. Edward III sebagaimana dideskripsikan oleh A.G. Subarsono' 2011 secara bersama sama dapat di gunakan pada lokasi penelitian yang diteliti di karenakan berpengaruh sangat kuat terhadap Pembentukan pola ruang permukiman di Kecamatan Bissappu.

\section{Kesimpulan dan Saran}

Berdasarkan rumusan masalah dan tujuan penelitian maka dari hasil penelitian dan pembahasan pada bab IV maka dapat ditarik kesimpulan antara lain :

1. Melihat dari hasil perhitungan diatas maka pengaruh Sumberdaya manusia $\left(\mathrm{X}_{1}\right)$ terhadap pembentukan pola ruang (Y) mempunyai hasil korelasi sedang yaitu 0,421 dimana $\mathrm{r}_{\text {hitung }}<\mathrm{r}_{\text {tabel }}=0,878$ pada taraf signifikansi alpha 0.05 maka $\mathrm{H} 0$ diterima dan $\mathrm{H} 1$ ditolak. Hal ini membuktikan bahwa peningkatan kualitas sumberdaya manusia (pegawai) tidak memiliki keterhubungan yang berati terhadap pembentukan pola ruang.

2. Hasil analisis perhitungan korelasi pada bab IV menunjukkan bahwa implementasi kebijakan $\left(\mathrm{X}_{2}\right)$ memiliki kerterhubungan yang sangat kuat terhadap pembentukan pola ruang(Y). Keberhasilan penerapan implementasi kebijakan pelayanan IMB maka semakin kuat pengaruhnya terhadap pembentukan pola ruang dimana rhitung $=0,9805$ lebih besar dari $\mathrm{r}$ tabel $=0.878$ pada taraf signifikansi $5 \%$ dimana $\mathrm{H} 0$ dtolak dan $\mathrm{H} 1$ diterima.

3. Hasil pengujian dan perhitungan analisis korelasi terhadap Variabel peningkatan Kualitas sumberdaya manusia(pegawai) $\left(\mathrm{X}_{1}\right)$ dan Implementasi $\operatorname{Kebijakan}\left(\mathrm{X}_{2}\right) \quad$ secara bersama-sama memiliki keterhubungan sangat kuat terhadap Pembentukan Pola ruang sebesar 0.9801. Dimana jika $R_{\text {hitung }}$ lebih besar dari $\mathrm{R}_{\text {tabel }}$ sebesar 0,878 , pada taraf signifikansi alpha adalah 0.05 , maka $\mathrm{H} 0$ di tolak dan $\mathrm{H} 1$ diterima.

Saran-saran yang dapat dikemukakan berkenaan dengan hasil penelitian ini bahwa kualitas sumberdaya manusia perlu ditingkatkan tidak hanya pengembangan kualitas melalui pendidikan kan tetapi dapat pula mengikuti pelatihan-pelatihan, bimbingan teknis, mempunyai ketrampilan sehingga pada penerapan pelayanan rekomendasi izin mendirikan bangunan terhadap pembentukan pola akan ruang lebih meningkat.

\section{Daftar Pustaka}

AG. Subarsono. 2011. Analisis Kebijakan Publik (konsep. teori dan aplikasi).Yogyakarta: Pustaka Pelajar.

Hasibuan, Malayu Sp. 2012. Manajemen SDM. Edisi Revisi, Cetakan Ke Tigabelas. Jakarta : Bumi Aksara.

Iqbal, M dan Sumaryanto. 2007. Strategi Pengendalian Alih Fungsi Lahan Pertanian Bertumpu pada Partisipasi Masyarakat. Bogor: Pusat Analisis Sosial Ekonomi dan Kebijakan Pertanian.

Maurinus Roy A C, Omo Rusdiana, Iin Ichwandi, 2017. The Changing Dynamic and Space Utilization Policy in Bogor District, West Java Province. Journal of Env. Engineering \& Waste Management, Vol. 2, No. 2, Oktober 2017. 
Peraturan Daerah Nomor 2 Tahun 2012 tentang Rencana Tata ruang wilayah Kabupaten Bantaeng.

Soekidjo Notoatmodjo. 2009. Pengembangan Sumber Daya Manusia. Jakarta: Rineka Cipta.

Sugiyono. (2013). Metode Penelitian Kuantitatif, Kualitatif dan R\&D. Bandung: Alfabeta.CV

Undang-Undang Nomor 26 tahun 2007 Tentang Penataan Ruang. 